\section{Morphology and Flowering Responses of Four Bedding Plant Species to a Range of Red to Far Red Ratios}

\author{
Jasmine J. Mah, David Llewellyn, and Youbin Zheng ${ }^{1}$ \\ School of Environmental Sciences, University of Guelph, 50 Stone Road East, \\ Guelph, ON N1G 2W1, Canada
}

Additional index words. LED, controlled environment, R:FR, calibrachoa, geranium, marigold, petunia

\begin{abstract}
In greenhouse ornamental crop production, bedding plants grown below high densities of hanging baskets (HBs) tend to be of lower quality. Hanging basket crops can decrease the red to far red ratio (R:FR) of the growing environment below; however, the extent to which decreased R:FR affects plant morphology and flowering of the lowerlevel crops is unknown. The present study examined effects of R:FR on morphology and flowering of marigold 'Antigua Orange' (Tagetes erecta), petunia 'Duvet Red' (Petunia $\times$ hybrida), calibrachoa 'Kabloom Deep Blue' (Calibrachoa $\times$ hybrida), and geranium 'Pinto Premium Salmon' (Pelargonium $\times$ hortorum). Five R:FR light treatments were provided ranging from R:FR 1.1 (representing unfiltered sunlight) to R:FR 0.7 (representing shaded conditions under HBs) using light-emitting diodes (LEDs) in growth chambers, each with identical photosynthetically active radiation $(P A R)(400$ $700 \mathrm{~nm}$ ) and $F R$ added to achieve the target $R$ :FR ratio. Two experiments using the same R:FR treatments were conducted with day/night temperature regimes of $20^{\circ} \mathrm{C} / 18{ }^{\circ} \mathrm{C}$ and $25{ }^{\circ} \mathrm{C} / 21{ }^{\circ} \mathrm{C}$, respectively. In the second experiment, a fluorescent light treatment was included. The results of the second experiment were more dramatic than the first, where reducing $R$ :FR from 1.1 to 0.7 increased height by $11 \%, 22 \%$, and $32 \%$ in marigold, petunia, and calibrachoa, respectively, and increased petiole length in geranium by $10 \%$. Compared with R:FR 1.1, the R:FR 0.7 shortened the time to the appearance of first flower bud by 2 days in marigold, whereas flowering was minimally affected in other species. Compared with pooled data from the LED treatments, fluorescent light increased relative chlorophyll content for all species, reduced height in marigold, petunia, calibrachoa, and geranium by $26 \%, 67 \%, 60 \%$, and $48 \%$, and reduced stem dry weight by $28 \%, 39 \%, 21 \%$, and $31 \%$, respectively. The differences in morphology observed under fluorescent light compared with LED R:FR treatments indicate that light quality manipulation is a potential alternative to chemical growth regulators in controlled environments such as greenhouses and growth chambers.
\end{abstract}

In greenhouse production, it has been observed that bedding plants tend to be of lower quality when grown below a dense canopy of HBs, characterized by elongated stems and reduced branching (Hamrick, 2003). Although it has been demonstrated that HBs alter both light quantity and quality (Faust et al., 2014; Llewellyn et al., 2013), the extent to which altered light quality beneath HBs contributes to changes in plant morphology is unknown. Research into the factors of the light environment which contribute to 'leggy' plants may also provide insight toward the use of light as a nonchemical plant growth regulator, which has been of growing interest in ornamental horticulture (Folta and Childers, 2008).

\footnotetext{
Received for publication 15 Nov. 2017. Accepted for publication $1 \mathrm{Feb} .2018$

We thank the Ontario Ministry of Agriculture, Food, and Rural Affairs and Heliospectra AB (Gothenburg, Sweden) for their financial support. We would also like to thank Mike Dixon and Albert Grimm for the informative discussions during the study.

1Corresponding author. E-mail: yzheng@uoguelph.ca.
}

with greatest $P P F$ interception resulting from the highest density of HBs, darkest pot color, and presence of plants. The reductions in $P P F$ at the lower crop-level because of high density HB production may result in a daily light integral (DLI) at or below the minimum requirement for 'good quality' bedding plants, which is considered to be $10-12 \mathrm{~mol} \cdot \mathrm{m}^{-2} \cdot \mathrm{d}^{-1}$ for greenhouse ornamental crops including Pelargonium hortorum, Tagetes ssp., and Petunia ssp. (Faust, 2003; Llewellyn et al., 2013).

Llewellyn et al. (2013) also reported reductions in R:FR under HBs. Reductions in $\mathrm{R}: \mathrm{FR}$ are commonly observed below foliage canopies, as green leaves absorb light strongly within the range of PAR (400-700 nm), including $\mathrm{R}$, whereas higher proportions of wavelengths longer than $700 \mathrm{~nm}$ are either reflected or transmitted to the surrounding environment (Gates et al., 1965; Holmes and Smith, 1977a). Accordingly, Llewellyn et al. (2013) reported a decrease in R:FR over the season (April to mid-May) as the light reaching the lower crop passed through an increasingly large canopy of HB foliage. At the lower crop level, the lowest R:FR measurement was 0.86 , whereas the average R:FR above HB level was 1.11. The average R:FR above HBs was similar to other reported values for unfiltered sunlight, generally ranging between 1.0 and 1.3 (Holmes and Smith, 1977b; Kittas et al., 1999). However, care should be taken when comparing values using other methods for calculating R:FR, which sometimes include the common narrowwaveband R:FR (R:FR ${ }_{\text {narrow }}, 660 \pm 5 \mathrm{~nm}: 730$ $\pm 5 \mathrm{~nm}$ ) (Holmes and Smith, 1977b; Meng and Runkle, 2014). The R:FR of sunlight at the Earth's surface is generally stable throughout the day when the solar elevation is greater than $15^{\circ}$ (Holmes and Smith, 1977b), although $\mathrm{R}: \mathrm{FR}$ is known to vary with geographic location (Goldberg and Klein, 1977).

Plant responses to R:FR have been extensively documented (Casal and Smith, 1989; Chen and Chory, 2011; Demotes-Mainard et al., 2016). Plants respond to R:FR via phytochrome, a class of pigments which interconvert between red-absorbing and farred-absorbing forms ( $P_{\mathrm{r}}$ and $P_{\mathrm{fr}}$, respectively) based on the proportion of $\mathrm{R}$ and FR photons illuminating the plant (Smith and Holmes, 1977). The proportion of these two forms within the plant, represented by the phytochrome photoequilibrium $\left(P_{\mathrm{fr}} / P\right)$, initiates a cascade of metabolic events ultimately influencing germination, flowering, and morphology (Blom et al., 1995; Chory et al., 1996). The R:FR is a reliable signal for plants indicating competition for light from nearby or overhead vegetation (Gates et al., 1965; Holmes and Smith, 1975). In many plant species, reduced R:FR contributes to 'shade avoidance' responses such as stem elongation and apical dominance as means to compete for available light (Casal, 2012; Casal and Smith, 1989; Chen and Chory, 2011; Smith and Whitelam, 1997). The ultimate phenotypic expression to low R:FR is species-specific and is codependent on other interacting factors, 
including temperature (Qaderi et al., 2015; Xiong et al., 2002) and absolute intensity of $\mathrm{R}$ and FR (Lund et al., 2007). There are limited studies of R:FR effects on bedding plants, including petunia (Petunia sp.), impatiens (Impatiens sp.), and marigold (Tagetes sp.) (Bachman and McMahon, 2006; Craig and Runkle, 2012; Fletcher et al., 2005). However, these studies vary widely in the range of R:FR investigated, as well as intensities and timing of R:FR treatment applications.

The objective of the present study was to quantify the effects of R:FR ranging from 0.7 to 1.1 on bedding plant morphology and flowering. This range captures the R:FR measured above and below HBs as measured by Llewellyn et al. (2013).

\section{Materials and Methods}

Two experiments (Expts. 1 and 2) were conducted sequentially in walk-in growth chambers at the University of Guelph, ON, Canada, from 2 May to 22 Sept. 2016. Environmental conditions were consistent across the two experiments except for temperature and relative humidity.

Seedling propagation. Seeds of petunia 'Duvet Red' (Petunia $\times$ hybrida) (Ball Horticultural Co., West Chicago, IL), marigold 'Antigua Orange' ( $T$. erecta) (Syngenta Flowers, Gilroy, CA), geranium 'Pinto Premium Salmon' (Pelargonium $\times$ hortorum) (Express Seed Company, Oberlin, $\mathrm{OH}$ ) and calibrachoa 'Kabloom Deep Blue' (Calibrachoa $\times$ hybrida) (PanAmerican Seed Co., West Chicago, IL) were sowed in 288-cell $(10 \mathrm{~mL})$ plug trays containing a commercial growth medium (Sunshine LP5 Plug Mix; Sun Gro Horticulture Distribution, Agawam, MA). Plug trays were placed in a walk-in growth chamber (floor area: $29.2 \mathrm{~m}^{2}$ ) under a panel of Sylvania $4200 \mathrm{~K}$ cool-white fluorescent lamps (F96T12/CW/WHO; LEDVANCE, Wilmington, MA). The light panel height was adjusted weekly to maintain a constant canopy-level $P P F$ of $200 \mu \mathrm{mol} \cdot \mathrm{m}^{-1} \cdot \mathrm{s}^{-1}$, measured with a LI-190 quantum sensor (LI-COR, Inc., Lincoln, NE) calibrated to a spectrometer. The chamber photoperiod was set to $16-\mathrm{h}$. Air temperature and relative humidity were set at constant $20^{\circ} \mathrm{C}$ and $60 \%$, respectively, for Expt. 1 and day/night temperatures were set at $25^{\circ} \mathrm{C} / 22^{\circ} \mathrm{C}$ for Expt. 2 . The $\mathrm{CO}_{2}$ concentration for both experiments was $\approx 440$ ppm.

Seedlings were top-irrigated as needed with tap water until cotyledons were visible on $50 \%$ of the plugs. Thereafter, groundwater supplemented with water-soluble fertilizer (20N-3.4P-16.6K All Purpose High Nitrate; Master Plant-Prod, Inc., Brampton, ON, Canada) was used for irrigation, providing (in $\left.\mathrm{mg} \cdot \mathrm{L}^{-1}\right) 250 \mathrm{~N}, 42 \mathrm{P}, 207 \mathrm{~K}, 1.8 \mathrm{Mg}, 1.2 \mathrm{Fe}$, $0.62 \mathrm{Mn}, \mathrm{Zn}$, and $\mathrm{Cu}, 0.25 \mathrm{~B}$, and $0.18 \mathrm{Mo}$. Two separate fertilizer solution tanks were adjusted to pH 5.5 (for petunia and calibrachoa) and $\mathrm{pH} 6.0$ (for geranium and marigold) using aqueous phosphoric acid. Uniform-sized seedlings were transplanted into 8.89 -cm-tall black plastic pots $(458 \mathrm{~mL})$ containing an all-purpose soilless substrate (Sunshine Mix \#1; Sun Gro Horticulture Distribution) when the roots could hold the shape of the substrate when gently pulled (22-42 d for Expt. 1, 17-28 d for Expt. 2). The growth chamber was divided into six treatment zones, separated by white vinyl curtains to prevent light contamination between treatments while allowing sufficient air flow to maintain air temperature and relative humidity. Each treatment area, or plot, was divided into four subplots $(2 \times 2$ grid). Each species was randomly assigned to one subplot and five uniformly sized sample plants of a given species were placed in its respective subplot. Border plants were placed around the outer edges of the plot. Over time, plants were spread further apart to prevent mutual shading, while keeping sample plants within the characterized light treatment plot area. Plants were rearranged within the subplots or the subplots were rotated within the plot at least every $3 \mathrm{~d}$ to reduce effects of nonuniform light distribution.

Plants were top-irrigated as needed by hand until minimal drainage was observed. Tap water was used for the first two irrigations after transplant. Thereafter, fertilizer solutions of either $\mathrm{pH} 6.0$ or 5.5 were used as previously described for seedlings before transplanting.

The day/night air temperatures (mean \pm SD), excluding $30 \mathrm{~min}$ after each day/night transition, were $20.4 \pm 0.6{ }^{\circ} \mathrm{C} / 18.3 \pm 0.5^{\circ} \mathrm{C}$ in Expt. 1 and $25.1 \pm 0.9^{\circ} \mathrm{C} / 21.4 \pm 0.3{ }^{\circ} \mathrm{C}$ (excluding fluorescent light treatment) in Expt. 2. When the lights were on, the fluorescent treatment plot was $1.5{ }^{\circ} \mathrm{C}$ higher than the average temperature of the LED treatment plots, but when the lights were off, all treatment plots had homogeneous temperatures. Average RH was $75 \% \pm 7 \%$ in Expt. 1 and $69 \% \pm 7 \%$ in Expt. 2.

Light treatments. In five of the six treatment zones, pairs of programmable LED lights (LX602C; Heliospectra AB, Gothenburg, Sweden) were suspended side by side (centers $38 \mathrm{~cm}$ apart), $60 \mathrm{~cm}$ above pot level. Each fixture had a rectangular array of 240 LEDs $(27.6 \mathrm{~cm} \times 16.8 \mathrm{~cm})$ comprised of blue $(450 \mathrm{~nm})$, white $(5700 \mathrm{~K})$, red $(660 \mathrm{~nm})$, and far red $(735 \mathrm{~nm})$ LEDs, as described by the manufacturer. In the second experiment, the fluorescent light panels used for plug development provided a sixth light treatment.

LED lamps were programmed using System Assistant Version 1.3.0 software (Heliospectra $\mathrm{AB}$ ). The photoperiod was 16 -h from 0900 to 0100 HR. The red and white LEDs provided the same pot-level $P P F$ and spectral distribution in all LED treatments. The blue channel was not used as the white LEDs provided sufficient blue light to give a $B: R$ ratio of almost 2:5. Far red settings were adjusted to target R:FR of $0.70,0.80$. 0.90 , 1.00 , and 1.10 for the treatments. The light treatments were rerandomized among the five LED plots for the second experiment. The fluorescent lights in Expt. 2 were programmed to the same photoperiod, and panelheight was adjusted to provide the same canopy-level $P P F$ as the LED treatments.
Light spectra were measured with a USB2000 + spectrometer equipped with a $1.5-\mathrm{m}$ long, 3900- $\mu \mathrm{m}$ diameter ultravioletVIS optical fiber with a CC-3 cosine corrector (OceanOptics, Dunedin, FL). The spectrometer was calibrated for absolute irradiance on 16 Mar. 2016 between 300 and $1050 \mathrm{~nm}$ using an LS-1 calibrating light source (OceanOptics). The average spectral distribution under each treatment was obtained from 25 points, measured at pot height on an equally spaced 5 -by-5 square grid covering a $56 \mathrm{~cm} \times 56 \mathrm{~cm}$ plot.

The peak wavelengths of the LED colors (mean \pm SD), averaged from all 25 points under each treatment, were $445.7 \pm 1.1 \mathrm{~nm}$ (blue peak of white channel), $659.5 \pm 0.7 \mathrm{~nm}$ (red), and $736.2 \pm 0.5 \mathrm{~nm}$ (far red) with full width at half maxima of $21 \pm 2.2 \mathrm{~nm}, 17 \pm 0.5 \mathrm{~nm}$, and $22 \pm 0.5 \mathrm{~nm}$, respectively, at treatment intensities.

The spectral irradiance data were converted from $\mu \mathrm{W} \cdot \mathrm{cm}^{-2} \cdot \mathrm{nm}^{-1}$ to $\mu \mathrm{mol} \cdot \mathrm{m}^{-2} \cdot \mathrm{s}^{-1} \cdot \mathrm{nm}^{-1}$, then multiplied by corresponding spectrometer pixel wave bandwidths and summed over the following ranges to calculate photon flux of blue (B, 400-500 nm), green $(\mathrm{G}$, 500-600 nm), R, and $P A R$, with B:G:R presented as percent of total $P A R$ in Table 1 . The R:FR photon flux ratio of each treatment was measured and described using wide $(\mathrm{R}$ : FR) and narrow (R:FR narrow$)$ wavebands, and $P_{\mathrm{fr}} / P$ was estimated for each treatment following Sager et al. (1988) and Sager and McFarlane (1997), also presented in Table 1. The wide-bandwidth R:FR was preferred over R:FR ${ }_{\text {narrow }}$ for analysis because a slight shift in LED peak wavelength could lead to a large percentage of the peak being truncated in a R:FR $\mathrm{Farrow}_{\text {calculation. This may }}$

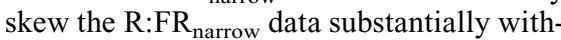
out a corresponding physiological response.

Because the fluorescent panel was initially positioned higher than the LED panels, over time, the canopy-level PPF under LEDs increased at a faster rate as plants grew. The relationship between height and average $P P F$ under LED treatments was determined before transplant with spectrometer measurements at five heights. After treatments commenced, average canopy-level $P P F$ under the LED treatments was calculated from canopy height measurements and the fluorescent panel height was adjusted weekly using a LI-190 quantum sensor calibrated to the spectrometer to match the canopy-level $P P F$ under LED treatments.

Mean PPF at pot level was 210.7 $\mu \mathrm{mol} \cdot \mathrm{m}^{-2} \cdot \mathrm{s}^{-1}$ (Expts. 1 and 2), corresponding to a DLI of $12.1 \mathrm{~mol} \cdot \mathrm{m}^{-2} \cdot \mathrm{d}^{-1}$. As the plants grew closer to the light fixtures, canopy-level $P P F$ increased to $266 \mu \mathrm{mol} \cdot \mathrm{m}^{-2} \cdot \mathrm{s}^{-1}$ (calculated based on canopy height), corresponding to a DLI of $15.3 \mathrm{~mol} \cdot \mathrm{m}^{-2} \cdot \mathrm{d}^{-1}$ at harvest

Data collection. Harvest dates were determined based on the development of reproductive structures, with one harvest date for each species. The harvest dates were chosen to be late enough to provide data relevant to generative tissue development whereas early enough to avoid excessive 
Table 1. Summary of light treatments in Expts. 1 and $2 .{ }^{2}$

\begin{tabular}{|c|c|c|c|c|c|c|c|}
\hline \multirow[b]{2}{*}{ Light treatment } & \multirow[b]{2}{*}{$\mathrm{R}: \mathrm{FR}^{\mathrm{y}}$} & \multirow[b]{2}{*}{$\mathrm{R}: \mathrm{FR}_{\text {narrow }}$} & \multirow[b]{2}{*}{ Estimated $P_{\mathrm{fr}} / P$} & \multicolumn{3}{|c|}{$P P F$} & \multirow[b]{2}{*}{$\mathrm{B}: \mathrm{G}: \mathrm{R}(\%)$} \\
\hline & & & & Max & Avg & Min & \\
\hline \multicolumn{8}{|l|}{ Expt. 1} \\
\hline LED R:FR 0.7 & $0.71 \pm 0.04$ & $0.73 \pm 0.07$ & 0.63 & 239.9 & $206.8 \pm 19.3$ & 174.5 & $19: 31: 50$ \\
\hline LED R:FR 0.8 & $0.79 \pm 0.04$ & $0.78 \pm 0.06$ & 0.65 & 251.3 & $213.1 \pm 22.4$ & 171.4 & $19: 31: 50$ \\
\hline LED R:FR 0.9 & $0.90 \pm 0.04$ & $0.91 \pm 0.06$ & 0.67 & 243.0 & $209.5 \pm 20.2$ & 167.6 & $19: 30: 51$ \\
\hline LED R:FR 1.0 & $1.00 \pm 0.05$ & $1.00 \pm 0.07$ & 0.69 & 252.3 & $213.1 \pm 22.7$ & 174.5 & $19: 31: 50$ \\
\hline LED R:FR 1.1 & $1.09 \pm 0.05$ & $1.04 \pm 0.05$ & 0.70 & 246.3 & $209.9 \pm 21.4$ & 168.9 & $19: 31: 50$ \\
\hline \multicolumn{8}{|l|}{ Expt. 2} \\
\hline LED R:FR 0.7 & $0.70 \pm 0.03$ & $0.73 \pm 0.02$ & 0.63 & 243.6 & $210.6 \pm 20.2$ & 168.3 & $19: 30: 51$ \\
\hline LED R:FR 0.8 & $0.80 \pm 0.04$ & $0.80 \pm 0.03$ & 0.65 & 247.0 & $210.3 \pm 22.5$ & 164.9 & $19: 31: 50$ \\
\hline LED R:FR 0.9 & $0.89 \pm 0.04$ & $0.87 \pm 0.02$ & 0.67 & 252.6 & $213.5 \pm 23.2$ & 171.2 & $19: 31: 50$ \\
\hline LED R:FR 1.0 & $1.00 \pm 0.05$ & $0.98 \pm 0.10$ & 0.69 & 238.7 & $205.9 \pm 19.2$ & 173.5 & $19: 31: 50$ \\
\hline LED R:FR 1.1 & $1.09 \pm 0.05$ & $1.08 \pm 0.06$ & 0.70 & 253.3 & $212.8 \pm 22.4$ & 174.7 & $19: 31: 50$ \\
\hline $\mathrm{WFL}^{\mathrm{w}}$ & $14.9 \pm 0.5$ & $9.6 \pm 0.6$ & 0.86 & 216.4 & $212.7 \pm 2.6$ & 206.3 & $18: 55: 27$ \\
\hline
\end{tabular}

${ }_{\mathrm{z}}$ Measurements were taken at 25 locations per treatment at pot height. All LED treatments used the same lamp settings for white, blue, and red channels with the far red channel adjusted to produce the target R:FR. ${ }^{\mathrm{y}}$ The R:FR $(600-700 \mathrm{~nm}: 700-800 \mathrm{~nm}), \mathrm{R}: \mathrm{FR}_{\text {narrow }}(655-665 \mathrm{~nm}: 725-735 \mathrm{~nm})$, estimated $P_{\mathrm{fr}} / P$, and average $P P F(400-700 \mathrm{~nm})$ are reported as mean $\pm \mathrm{SD}(n=25)$ with all calculations based on photon flux $\left(\mathrm{PF}, \mu \mathrm{mol} \cdot \mathrm{m}^{-2} \cdot \mathrm{s}^{-1}\right)$.

${ }^{x}$ Photon flux ratios of blue $(B, 400-500 \mathrm{~nm})$, green $(\mathrm{G}, 500-600 \mathrm{~nm})$, and red $(\mathrm{R}, 600-700)$ are reported as percentage of total $P P F$.

${ }^{\mathrm{w}}$ White fluorescent lamps (WFL) had PF for ultraviolet-A (320-400 nm) and ultraviolet-B (300-320 nm) of $1.60 \pm 0.06 \mu \mathrm{mol} \cdot \mathrm{m}^{-2} \cdot \mathrm{s}^{-1}$ and $0.08 \pm 0.01 \mu \mathrm{mol} \cdot \mathrm{m}^{-2} \cdot \mathrm{s}^{-1}$, respectively.

$\mathrm{R}: \mathrm{FR}=$ red to far red ratio; $P P F=$ photosynthetic photon flux.

mutual shading between plants. Marigolds were harvested before flowering, when the average apical flower stem length (all treatments combined) was more than $2.5 \mathrm{~cm}$. Petunia and calibrachoa were harvested when all plants in all treatments had at least one flower, and geraniums were harvested when flower buds were visible on more than $50 \%$ of all plants.

Plants were checked at least every $2 \mathrm{~d}$ for presence of generative tissues. Date of first bud and date of first flower were recorded on the first instance of a bud or open flower on each plant. A bud was counted for petunia and calibrachoa when developing petals were visible from any angle; for marigold, buds were counted when the white of the bud was visible; for geranium, buds were counted when any amount of flower stem was visible between the bud cluster and primary shoot. For calibrachoa, the number of nodes below the first bud was also recorded.

At harvest, all measurements for a species were recorded within a 24-h period except for dry weight. Nondestructive measurements common to all species were height, stem diameter, number of buds/inflorescences and flowers, and relative leaf chlorophyll content (SPAD units). Plant height was defined as length of the primary stem from substrate surface to shoot tip. If a terminal bud was present, as in marigolds, height was measured up to the last node where the flower stem emerged. For marigold, flower stem length (from the last node on primary stem to base of the flower bud) was also recorded. Stem diameter was measured immediately above the hypocotyl using a vernier caliper. The relative chlorophyll content for each plant was the average of three measurements from randomly selected newly fully expanded leaves using a SPAD-502Plus chlorophyll meter (Konica Minolta, Inc., Tokyo, Japan). Number of side branches was counted for petunia in Expt. 1, and for both petunia and calibrachoa in Expt. 2. Nodes on the primary stem were counted for all species except geranium, for which leaves were counted instead. For geranium, the length of the longest petiole on each plant was measured.

The destructive measurements included leaf area, leaf dry weight, and stem dry weight. Stems were severed at the substrate surface. Then, leaves were cut from stems at the leaf axil except for geraniums, for which leaves were cut below the leaf blade. Larger marigold leaves were dissected following a '2-mm rule': any part of the central vein wider than $2 \mathrm{~mm}$ was excised and placed in the stem category to prevent skew of the specific leaf area measurement (SLA; leaf area per unit leaf dry weight). All biomass above the substrate surface other than leaves were placed in the 'stem' category. Leaf area was measured with a leaf area meter (LI3100; LI-COR, Inc.). Leaves and stems were oven-dried separately at $65{ }^{\circ} \mathrm{C}$ for at least $5 \mathrm{~d}$ (until weight was constant) and weighed. Total dry weight (total DW; leaf dry weight + stem dry weight) was also calculated.

Statistical analysis. Statistical analysis was performed in RStudio (RStudio Team, 2016) using " $R$ " software version 3.3.1 (R Core Team, 2016). Significance for all analyses was defined at $P \leq 0.05$. Each measured variable was individually analyzed for linear and quadratic regression over the range of $\mathrm{R}$ : FR using the linear model function followed by analysis of variance, using sequential sums of squares. Only the best fit model equations are presented for variables with significant regressions, whereas overall means (pooled data from all LED treatments) are presented when there were no treatment effects for descriptive purposes. Packages used were "dplyr" (Wickham and Francois, 2016) for summary statistics and "agricolae" (de Mendiburu, 2016) for Tukey’s honestly significant difference post hoc test to check for differences between the fluorescent and pooled LED treatment data.

\section{Results}

Expt. 1

There were no treatment effects on final height or dry weight (Table 2) for all four species.

Calibrachoa. There were no treatment effects for any variable measured.

Petunia. Low R:FR resulted in greater number of nodes and earlier appearance of first bud (compared with higher R:FR) although there was no subsequent difference in days to first flower.

Geranium. Decreasing R:FR was associated with fewer leaves and reduced bud count.

Marigold. Stem diameter, leaf area, and SLA responded to R:FR quadratically. Stem diameter followed a positive parabolic function, with minimum at R:FR of 0.94 , whereas leaf area and SLA followed negative parabolic functions with maxima at R:FR of 0.89 and 0.91 , respectively.

During the experiment, an interesting observation was made. A few excess plants were kept in the unused chamber zone under fluorescent lights (initially used to produce the seedlings). These plants had noticeably darker green leaves and markedly shorter stems and internodes than the plants under any of the LED treatments. Hence, a fluorescent treatment was included in Expt. 2 to compare morphology between plants grown under fluorescent and LED treatments.

\section{Expt. 2}

A greater number of treatment effects were observed in Expt. 2 compared with Expt. 1. Some measures of height were affected in all species, as decreased R:FR increased the height (primary stem length) of marigold, petunia, and calibrachoa, and increased petiole length in geranium (Table 2).

Marigold. Plants treated with R:FR 0.7 had $11 \%$ greater height than those treated with R:FR 1.1 (i.e., $17.0 \mathrm{~cm}$ vs. $15.3 \mathrm{~cm}$ ). Lower R:FR (0.7) was also associated with earlier date of first flower bud by $\approx 2 \mathrm{~d}$, longer terminal flower bud stems, and greater stem and total dry weight than higher R: FR (1.1)

Petunia. Plants treated with R:FR 0.7 had $22 \%$ greater height than those treated with $\mathrm{R}$ : FR 1.1 (i.e., $12.5 \mathrm{~cm}$ vs. $10.2 \mathrm{~cm}$ ). Petunia leaf area and leaf dry weight both followed positive quadratic trends, with minima at $\mathrm{R}$ : FR 0.89 and 0.90 , respectively

Calibrachoa. Plants treated with R:FR 0.7 had $32 \%$ greater height than those treated with R:FR 1.1 (i.e., $40.7 \mathrm{~cm}$ vs. $30.7 \mathrm{~cm}$ ).

Geranium. Plants treated with R:FR 0.7, length of the longest petiole was $10 \%$ greater than those treated with R:FR 1.1 (i.e., $10.9 \mathrm{~cm}$ vs. $9.9 \mathrm{~cm}$ ). 
Table 2. Effects of R:FR (0.7-1.1) on growth and flowering of marigold, petunia, calibrachoa, and geranium in Expts. 1 and 2.

\begin{tabular}{|c|c|c|c|c|}
\hline \multirow[b]{2}{*}{ Measurement } & \multicolumn{2}{|l|}{ Expt. 1} & \multicolumn{2}{|l|}{ Expt. 2} \\
\hline & Regression equation or avg & $r^{2}$ & Regression equation or avg & $r^{2}$ \\
\hline Height $(\mathrm{cm})$ & $10.4 \pm 0.2$ & & $y=19.9-4.2 x$ & 0.18 \\
\hline Flower stem length $(\mathrm{cm})$ & $2.9 \pm 0.1$ & & $y=6.4-4.1 x$ & 0.25 \\
\hline Stem diameter $(\mathrm{mm})$ & $y=19.3-24.5 x+13.0 x^{2}$ & 0.28 & $9.4 \pm 0.1$ & \\
\hline Leaf area $\left(\mathrm{cm}^{2}\right)$ & $y=-859+3,574 x-2,006 x^{2}$ & 0.26 & $1,312 \pm 13$ & \\
\hline Leaf dry weight (g) & $2.41 \pm 0.04$ & & $4.19 \pm 0.04$ & \\
\hline SLA $\left(\mathrm{cm}^{2} \cdot \mathrm{g}^{-1}\right)$ & $y=-270+1,262 x-696 x^{2}$ & 0.49 & $313 \pm 3$ & \\
\hline Bud count & $9.8 \pm 0.4$ & & $8.6 \pm 0.4$ & \\
\hline Days to first bud (DAT) & $17.4 \pm 0.4$ & & $y=12.6+5.6 x$ & 0.19 \\
\hline \multicolumn{5}{|l|}{ Petunia } \\
\hline Height $(\mathrm{cm})$ & $16.6 \pm 0.4$ & & $y=16.4-5.6 x$ & 0.16 \\
\hline Nodes (no.) & $y=10.0-3.1 x$ & 0.22 & $5.1 \pm 0.1$ & \\
\hline Stem diameter $(\mathrm{mm})$ & $4.6 \pm 0.1$ & & $4.4 \pm 0.1$ & \\
\hline SLA $\left(\mathrm{cm}^{2} \cdot \mathrm{g}^{-1}\right)$ & $441 \pm 6$ & & $445 \pm 5$ & \\
\hline Flower and bud count & $34.4 \pm 1.3$ & & $16.8 \pm 0.3$ & \\
\hline Days to first bud (DAT) & $y=4.6+4.8 x$ & 0.20 & $10.2 \pm 0.2$ & \\
\hline Days to first flower (DAT) & $17.4 \pm 0.5$ & & $16.3 \pm 0.3$ & \\
\hline \multicolumn{5}{|l|}{ Calibrachoa } \\
\hline Height $(\mathrm{cm})$ & $32.3 \pm 1.0$ & & $y=58.1-24.9 x$ & 0.27 \\
\hline Nodes (no.) & $26.1 \pm 0.8$ & & $25.4 \pm 0.5$ & \\
\hline Stem diameter $(\mathrm{mm})$ & $3.2 \pm 0.1$ & & $3.0 \pm 0.1$ & \\
\hline Branches (no.) & NA & & $21.5 \pm 0.8$ & \\
\hline Leaf area $\left(\mathrm{cm}^{2}\right)$ & $600 \pm 34$ & & $498 \pm 23$ & \\
\hline Leaf dry weight (g) & $2.58 \pm 0.14$ & & $1.38 \pm 0.06$ & \\
\hline Stem dry weight (g) & $2.12 \pm 0.11$ & & $1.51 \pm 0.06$ & \\
\hline Total dry weight (g) & $4.70 \pm 0.23$ & & $2.89 \pm 0.12$ & \\
\hline Leaf area $\left(\mathrm{cm}^{2}\right)$ & $585 \pm 22$ & & $526 \pm 11$ & \\
\hline Leaf dry weight (g) & $3.35 \pm 0.16$ & & $2.46 \pm 0.07$ & \\
\hline Stem dry weight (g) & $1.34 \pm 0.06$ & & $0.81 \pm 0.02$ & \\
\hline Total dry weight (g) & $4.69 \pm 0.22$ & & $3.27 \pm 0.08$ & \\
\hline SLA $\left(\mathrm{cm}^{2} \cdot \mathrm{g}^{-1}\right)$ & $179 \pm 5$ & & $215 \pm 4$ & \\
\hline Bud count & $y=-1.0+1.7 x$ & 0.22 & $0.6 \pm 0.1$ & \\
\hline
\end{tabular}

${ }^{\mathrm{z}}$ Variables with significant $(P \leq 0.05)$ linear or quadratic regressions over R:FR are presented as equations; for nonsignificant variables, mean $\pm \operatorname{SE}(n=25)$ is presented for descriptive purposes.

SLA $=$ specific leaf area; DAT $=$ days after transplant; NA $=$ not applicable.

\section{Fluorescent versus LED treatments in Expt. 2}

Compared with the means of pooled data for LED treatments, all species under fluorescent light had reduced height, reduced stem dry weight, and increased relative chlorophyll content (SPAD) (Table 3). Overall, plants grown under fluorescent lights were visually more compact.

Height, dry weight, petiole length, and stem diameter. Under fluorescent light, marigolds, petunias, calibrachoas, and geraniums were $26 \%, 67 \%, 60 \%$, and $48 \%$ shorter, and had $28 \%, 39 \%, 21 \%$, and $31 \%$ lower stem dry weights, respectively.

Under fluorescent light, marigold leaf dry weight was reduced by $8 \%$, and total dry weight was reduced in all species except for calibrachoa. For geraniums, the length of the longest petiole under fluorescent light was $46 \%$ shorter than under the LED treatments. Although reduction in dry weight primarily occurred in the stems, stem diameter was unaffected in all species. It follows that the reductions in dry weight could be primarily accounted for by shorter stems, and also shorter petioles in geraniums.

Number of nodes and leaves, branching, and flowering. Marigold and petunia had $9 \%$ and $22 \%$ fewer nodes on the primary stem, respectively, under fluorescent light. Geraniums had $12 \%$ more leaves under fluorescent lights. There were no differences in branching in petunia and calibrachoa between fluorescent and LED treatments. The days to first bud and first flower were unaffected for all species. The only treatment effect pertaining to flowering was the total number of buds and flowers in petunia, with $38 \%$ fewer buds and flowers under fluorescent lights than under LEDs.

Leaf area, SLA. The only treatment effect for leaf area was $13 \%$ reduction in that of marigold under fluorescent vs. LEDs. Specific leaf area, however, was reduced under florescent lights in both marigold and calibrachoa by $5 \%$ and $19 \%$, respectively.

Leaf color and relative chlorophyll content. The relative chlorophyll content (SPAD) for all species was higher under fluorescent light (Table 3), where leaves were also observably darker green in color when viewed under a common light environment. Geranium leaves also had starker 
Table 3. Growth and flowering of marigold, petunia, geranium, and calibrachoa under fluorescent light and LEDs ${ }^{\mathrm{z}}$ in Expt. 2.

\begin{tabular}{|c|c|c|}
\hline Measurement & Fluorescent & LED \\
\hline \multicolumn{3}{|l|}{$\overline{\text { Marigold }}$} \\
\hline Height $(\mathrm{cm})$ & $11.9 \pm 0.4 \mathrm{~b}$ & $16.1 \pm 0.3 \mathrm{a}$ \\
\hline Flower stem length $(\mathrm{cm})$ & $2.6 \pm 0.3 \mathrm{a}$ & $2.7 \pm 0.2 \mathrm{a}$ \\
\hline Nodes (No.) & $10.6 \pm 0.4 b$ & $11.6 \pm 0.2 \mathrm{a}$ \\
\hline Stem diameter $(\mathrm{mm})$ & $9.5 \pm 0.3 \mathrm{a}$ & $9.4 \pm 0.1 \mathrm{a}$ \\
\hline Leaf area $\left(\mathrm{cm}^{2}\right)$ & $1,147 \pm 30 b$ & $1,312 \pm 12 \mathrm{a}$ \\
\hline Leaf dry weight (g) & $3.87 \pm 0.10 \mathrm{~b}$ & $4.19 \pm 0.04 \mathrm{a}$ \\
\hline Stem dry weight (g) & $2.85 \pm 0.14 \mathrm{~b}$ & $3.84 \pm 0.07 \mathrm{a}$ \\
\hline Total dry weight (g) & $6.72 \pm 0.22 b$ & $8.02 \pm 0.08 \mathrm{a}$ \\
\hline $\operatorname{SLA}\left(\mathrm{cm}^{2} \cdot \mathrm{g}^{-1}\right)$ & $297 \pm 8 b$ & $314 \pm 3 \mathrm{a}$ \\
\hline Bud count & $9.6 \pm 0.7 \mathrm{a}$ & $8.6 \pm 0.4 \mathrm{a}$ \\
\hline Days to first bud (DAT) & $16.0 \pm 0.0 \mathrm{a}$ & $17.6 \pm 0.4 \mathrm{a}$ \\
\hline SPAD $^{y}$ & $67.8 \pm 1.2 \mathrm{a}$ & $53.5 \pm 0.6 \mathrm{~b}$ \\
\hline \multicolumn{3}{|l|}{ Petunia } \\
\hline Height $(\mathrm{cm})$ & $3.7 \pm 0.2 \mathrm{~b}$ & $11.3 \pm 0.4 \mathrm{a}$ \\
\hline Nodes (No.) & $4.0 \pm 0.0 \mathrm{~b}$ & $5.1 \pm 0.1 \mathrm{a}$ \\
\hline Stem diameter $(\mathrm{mm})$ & $4.7 \pm 0.1 \mathrm{a}$ & $4.4 \pm 0.1 \mathrm{a}$ \\
\hline Branches (No.) & $10.2 \pm 0.2 \mathrm{a}$ & $10.4 \pm 0.2 \mathrm{a}$ \\
\hline Leaf area $\left(\mathrm{cm}^{2}\right)$ & $524 \pm 47 \mathrm{a}$ & $551 \pm 8 \mathrm{a}$ \\
\hline Leaf dry weight (g) & $1.19 \pm 0.08 \mathrm{a}$ & $1.24 \pm 0.02 \mathrm{a}$ \\
\hline Stem dry weight (g) & $0.82 \pm 0.04 \mathrm{~b}$ & $1.34 \pm 0.03 \mathrm{a}$ \\
\hline Total dry weight (g) & $2.01 \pm 0.09 \mathrm{~b}$ & $2.58 \pm 0.04 \mathrm{a}$ \\
\hline $\operatorname{SLA}\left(\mathrm{cm}^{2} \cdot \mathrm{g}^{-1}\right)$ & $438 \pm 12 \mathrm{a}$ & $445 \pm 5 \mathrm{a}$ \\
\hline Flower and bud count & $10.4 \pm 1.0 \mathrm{~b}$ & $16.8 \pm 0.3 \mathrm{a}$ \\
\hline Days to first bud (DAT) & $10.0 \pm 0.0 \mathrm{a}$ & $10.2 \pm 0.2 \mathrm{a}$ \\
\hline Days to first flower (DAT) & $16.4 \pm 0.7 \mathrm{a}$ & $16.3 \pm 0.3 \mathrm{a}$ \\
\hline SPAD & $49.6 \pm 1.0 \mathrm{a}$ & $43.3 \pm 0.5 \mathrm{~b}$ \\
\hline \multicolumn{3}{|l|}{ Geranium } \\
\hline Height $(\mathrm{cm})$ & $4.9 \pm 0.2 b$ & $9.5 \pm 0.2 \mathrm{a}$ \\
\hline Longest petiole $(\mathrm{cm})$ & $5.6 \pm 0.0 \mathrm{~b}$ & $10.3 \pm 0.1 \mathrm{a}$ \\
\hline Leaves (No.) & $11.6 \pm 0.2 \mathrm{a}$ & $10.4 \pm 0.1 \mathrm{~b}$ \\
\hline Stem diameter (mm) & $8.6 \pm 0.3 \mathrm{a}$ & $8.9 \pm 0.1 \mathrm{a}$ \\
\hline Leaf area $\left(\mathrm{cm}^{2}\right)$ & $476 \pm 21 \mathrm{a}$ & $526 \pm 11 \mathrm{a}$ \\
\hline Leaf dry weight (g) & $2.19 \pm 0.15 \mathrm{a}$ & $2.46 \pm 0.07 \mathrm{a}$ \\
\hline Stem dry weight (g) & $0.56 \pm 0.03 \mathrm{~b}$ & $0.81 \pm 0.02 \mathrm{a}$ \\
\hline Total dry weight (g) & $2.74 \pm 0.18 b$ & $3.27 \pm 0.08 \mathrm{a}$ \\
\hline SLA $\left(\mathrm{cm}^{2} \cdot \mathrm{g}^{-1}\right)$ & $219 \pm 6 \mathrm{a}$ & $215 \pm 4 \mathrm{a}$ \\
\hline Bud count & $0.6 \pm 0.2 \mathrm{a}$ & $0.6 \pm 0.1 \mathrm{a}$ \\
\hline SPAD & $39.7 \pm 1.1 \mathrm{a}$ & $35.0 \pm 0.8 \mathrm{~b}$ \\
\hline \multicolumn{3}{|l|}{ Calibrachoa } \\
\hline Height $(\mathrm{cm})$ & $14.2 \pm 1.6 \mathrm{~b}$ & $35.9 \pm 1.4 \mathrm{a}$ \\
\hline Nodes (No.) & $24.8 \pm 1.0 \mathrm{a}$ & $25.4 \pm 0.5 \mathrm{a}$ \\
\hline Stem diameter (mm) & $2.8 \pm 0.1 \mathrm{a}$ & $3.0 \pm 0.1 \mathrm{a}$ \\
\hline Branches (No.) & $25.4 \pm 2.0 \mathrm{a}$ & $21.5 \pm 0.8 \mathrm{a}$ \\
\hline Leaf area $\left(\mathrm{cm}^{2}\right)$ & $459 \pm 36 \mathrm{a}$ & $498 \pm 23 \mathrm{a}$ \\
\hline Leaf dry weight (g) & $1.57 \pm 0.12 \mathrm{a}$ & $1.38 \pm 0.06 \mathrm{a}$ \\
\hline Stem dry weight (g) & $1.19 \pm 0.11 \mathrm{~b}$ & $1.51 \pm 0.06 \mathrm{a}$ \\
\hline Total dry weight (g) & $2.76 \pm 0.20 \mathrm{a}$ & $2.89 \pm 0.12 \mathrm{a}$ \\
\hline SLA $\left(\mathrm{cm}^{2} \cdot \mathrm{g}^{-1}\right)$ & $293 \pm 14 b$ & $360 \pm 7 a$ \\
\hline Flower and bud count & $19.2 \pm 1.9 \mathrm{a}$ & $19.7 \pm 1.4 \mathrm{a}$ \\
\hline Days to first flower (DAT) & $21.2 \pm 0.6 \mathrm{a}$ & $20.4 \pm 0.4 \mathrm{a}$ \\
\hline Node of first flower & $20.8 \pm 1.0 \mathrm{a}$ & $20.6 \pm 0.4 \mathrm{a}$ \\
\hline SPAD & $58.5 \pm 1.7 \mathrm{a}$ & $39.6 \pm 0.7 \mathrm{~b}$ \\
\hline
\end{tabular}

${ }^{\mathrm{z}}$ Data for all LED treatments were pooled (mean $\pm \mathrm{SE} ; n=25$ ) and compared with the cool-white fluorescent (mean $\pm \mathrm{SE} ; n=5$ ) treatment using Tukey's honestly significant difference test. Data in the same row with different letters are significantly different $(P<0.05)$.

${ }^{\mathrm{y}} \mathrm{SPAD}$ units represent relative chlorophyll content.

SLA $=$ specific leaf area; DAT $=$ days after transplant

leaf variegation pattern under fluorescent lights.

\section{Discussion}

Effects of R:FR on growth and morphology of bedding plants. Plant growth and morphology were affected over the R:FR range of $0.7-1.1$, which corresponds to the range measured under HBs in greenhouses in Southern Ontario, Canada, during early spring. Some metrics responded differently between experiments such as height, petiole end-of-day in Petunia $\times$ hybrida (Bachman and McMahon, 2006; Ilias and Rajapakse, 2005), zinnia, chrysanthemum, cosmos (Cerny et al., 2003), impatiens (Fletcher et al., 2005), squash rootstock (Yang et al., 2012), Cucurbita pepo, Chenopodium album (Holmes and Smith, 1977c), soybean (Kasperbauer, 1987), tobacco (Kasperbauer and Peaslee, 1973), and other dicotyledonous species (Demotes-Mainard et al., 2016). The different responses to R:FR between Expts. 1 and 2 might be related to temperature differences, as several studies have reported interactions between R:FR and day/night temperature differential (DIF) (Blom and Kerec, 2003; Kubota et al., 2000; Moe et al., 1991; Xiong et al., 2011) or with absolute temperature (higher or lower with the same DIF) (Qaderi et al., 2015) on the stem length of various species, where low R: FR combined with positive DIF or higher absolute temperatures result in longer stem length.

Reductions in $P A R$ have also been implicated as an influential factor promoting stem elongation under HBs, as the DLI may fall below minimum requirements for "good quality" plants in greenhouse production (Faust, 2003; Llewellyn et al., 2013). However, interaction between R:FR and irradiance was not investigated and cannot be ruled out, as evidence suggests that phytochrome B (phyB), which is considered to be the main photoreceptor for shade-avoidance responses, has an integrated response to R:FR and irradiance on the subcellular level (Trupkin et al., 2014). More specifically, lowering irradiance (from 200 to 25 $\mu \mathrm{mol} \cdot \mathrm{m}^{-2} \cdot \mathrm{s}^{-1}$ ) in addition to lower R:FR (from 4.3 to 0.8 ) had compounding effects on the number and size of phyB nuclear bodies within Arabidopsis petiole cells (phyB in the nucleus is related to phytochrome activity, as phyB migrates from the cytosol to the cell nucleus only in the 'active' $P_{\mathrm{fr}}$ form).

Effects of R:FR on flowering. The R:FR had limited effects on flower development. For petunia in Expt. 1, lower R:FR was associated with earlier date of first bud, but there was subsequently no difference in the date of first flower. For geraniums, lower R: FR was associated with reduced bud count, which in this case may be interpreted as a delay in flowering; because plants had 0 or 1 bud, treatments with lower average bud numbers had a higher proportion of plants with no buds at the time of harvest. In Expt. 2, lower R:FR stimulated flowering in marigold, with R:FR 0.7 producing an earlier date of first bud by $\approx 2 \mathrm{~d}$ and longer terminal flower stems than R:FR 1.1. Although the effects on flowering were subtle, results for marigold and petunia agree with other studies which reported that a reduced R: FR can accelerate flower development (Ilias and Rajapakse, 2005), or conversely that an FR-deficient environment (increased R:FR) can delay flower initiation (Cerny et al., 2003; Runkle and Heins, 2001), especially in long-day plants. 
Differences between LED and fluorescent treatments (Expt. 2). Some of the pooled data for plants grown under LED treatments were substantially different from the fluorescent treatment plants. Common effects across all four species were reduced height, reduced stem dry weight, and increased relative chlorophyll content under fluorescent light. There were no differences in flower development except for petunia, for which there were greater number of total buds and flowers at harvest in the fluorescent treatment.

There are many features of the fluorescent spectral distribution that may have affected morphological responses. For example, in comparison with the LED treatments, fluorescent light had higher R:FR (14.9 vs. $\leq 1.1$ ), presence of ultraviolet-A and ultraviolet-B, higher $\mathrm{G}$ photon flux, lower $\mathrm{R}$ photon flux, and a correspondingly higher $\mathrm{B}$ : $\mathrm{R}(2: 3$ vs. $\approx 2: 5)$ as the $\mathrm{B}$ photon flux and percent $\mathrm{B}$ of $P P F$ were similar for all treatments (Table 1). A higher R:FR, higher blue (relative or absolute amount), and presence of ultraviolet have been implicated in the inhibition of stem elongation (Cope and Bugbee, 2013; Fletcher et al., 2005; Hernández and Kubota, 2016; Wargent, 2016).

Reductions in stem DW and higher relative chlorophyll content of fluorescent-grown plants could also be due to multiple factors including ultraviolet and high intensity green. In lettuce, the removal of ultraviolet in a greenhouse setting using selective filters was associated with increased dry weight (Tsormpatsidis et al., 2008). With regard to green light, Kim et al. (2004) found that higher intensities of green light $(51 \%$ and $86 \%$ of $P P F$ ) provided in growth chambers resulted in lower dry weight of lettuce compared with lower intensity of green $(24 \%$ of $P P F$ ) with the same total $P P F$. However, because the high-intensity green treatments in Kim et al. (2004) emitted more ultraviolet light than the lower-intensity green treatments, it is also possible that the effects of ultraviolet were conflated with elevated levels of green. Higher B:R has also been associated with reduced DW in lettuce (Son and Oh, 2013) but was attributed to a reduction in leaf area; a phenomenon which was not observed in our experiment except in marigold. It is also worth noting that Son and Oh (2013) achieved their different B:R by varying both $B$ and $R$ intensities, whereas in our study, fluorescent spectrum had a higher $B: R$ because of a lower R intensity only, meaning the absolute amount of $B$ was the same in both LED and fluorescent treatments.

Similar to the relative chlorophyll content results of the present study, Johkan et al. (2010) found that fluorescent light-induced higher chlorophyll content in sole source lettuce production than a combination of $R$ and B LEDs. This indicates that lower R:FR may not be the only reason why plants grown with fluorescent light had higher relative chlorophyll contents than those grown under LEDs in this study. Still, it is possible that the lower R:FR provided by LED treatments may have had a further effect to reduce chlorophyll and variegation patterns, similar to $\mathrm{Li}$ and Kubota (2009) who found that supplemental FR resulted in reduced chlorophyll and anthocyanins in lettuce. Other studies have reported reduced chlorophyll content in response to low R:FR in a variety of species (Heraut-Bron et al., 1999; Smith and Whitelam, 1997; Tucker, 1981). The presence of ultraviolet, which has been associated with elevated anthocyanin pigments in lettuce (Tsormpatsidis et al., 2008), baby leaf lettuce (Li and Kubota, 2009), and turnip hypocotyls (Zhou et al., 2007), may have also contributed to the increased leaf variegation in geranium grown under fluorescent lights as anthocyanins have been found to be abundant in zonal dark rings of Pelargonium $\times$ hortorum leaves (Liakopoulos and Spanorigas, 2012).

In summary, although the specific causes of morphological difference in the fluorescent treatment are uncertain, the results show the potential for light spectrum manipulations to induce changes to morphology and flowering.

There were three noteworthy differences between the growth chamber experiments and realistic greenhouse conditions which could affect the transferability of the results. Although the LED treatments provided wavelengths in blue, green, and red wavebands, solar spectral ratios were not replicated. The LED treatments had a B:G:R of 19:31:50 whereas solar radiation was measured to be $\approx 28: 37: 35$ (measured on a mostly clear day on $8 \mathrm{Feb} .2017$ at lat. $42^{\circ} \mathrm{N}$, data not shown). In addition, the $P P F$ in the growth chamber was constant throughout the photoperiod, whereas $P P F$ in a greenhouse follows a variable, diurnal pattern with instantaneous $P P F$ being highly influenced by outdoor weather. Differences in temperature may also interact with R:FR to influence transferability of results to commercial production.

\section{Conclusion}

This study investigated the effects of $\mathrm{R}: F R$ on morphology and flowering of marigold, petunia, calibrachoa, and geranium under the range of R:FR $(0.7-1.1)$ found in commercial greenhouse production scenarios where a canopy of HBs is grown above the bench level. Although light treatment effects were found, the crop responses were generally not considered commercially relevant because of similar appearances between plants grown under different treatments.

In terms of the potential of using light as a growth regulator, the fluorescent treatment provided evidence that spectral manipulation could be used to control growth, as plants grown under fluorescent lights showed noticeable differences in qualitative factors such as leaf coloration and stem elongation. Any of the distinct spectral parameters in fluorescent lights are candidates for further investigation toward using light as a growth regulator in a greenhouse setting, including increased R:FR, presence of ultraviolet-A or ultraviolet-B, or increased B:R. Further research is needed to determine whether spectral manipulation can be used to create commercially relevant outcomes.

\section{Literature Cited}

Bachman, G.R. and M.J. McMahon. 2006. Day and night temperature differential (DIF) or the absence of far-red light alters cell elongation in "Celebrity White" petunia. J. Amer. Soc. Hort. Sci. 131:309-312.

Blom, T. and D. Kerec. 2003. Effects of far-red light/temperature DIF and far-red light/temperature pulse combinations on height of lily hybrids. J. Hort. Sci. Biotechnol. 78:278-282.

Blom, T.J., M.J. Tsujita, and G.L. Roberts. 1995. Far-red at end of day and reduced irradience affect plant height of Easter and Asiatic hybrid lilies. HortScience 30:1009-1012.

Brown, W. 2014. The Ontario greenhouse floriculture industry. Ontario Ministry of Agriculture, Food and Rural Affairs. Queen's Printer for Ontario, Toronto, Canada.

Casal, J.J. 2012. Shade avoidance. Arab. Book Amer. Soc. Plant Biol. 10:e157.

Casal, J.J. and H. Smith. 1989. The function, action and adaptive significance of phytochrome in light-grown plants. Plant Cell Environ. 12:855862.

Cerny, T.A., J.E. Faust, D.R. Layne, and N.C. Rajapakse. 2003. Influence of photoselective films and growing season on stem growth and flowering of six plant species. J. Amer. Soc. Hort. Sci. 128:486-491.

Chen, M. and J. Chory. 2011. Phytochrome signaling mechanisms and the control of plant development. Trends Cell Biol. 21:664-671

Chory, J., M. Chatterjee, R.K. Cook, T. Elich, C. Fankhauser, J. Li, P. Nagpal, M. Neff, A. Pepper, D. Poole, J. Reed, and V. Vitart. 1996. From seed germination to flowering, light controls plant development via the pigment phytochrome. Proc. Natl. Acad. Sci. USA 93:12066-12071.

Cope, K.R. and B. Bugbee. 2013. Spectral effects of three types of white light-emitting diodes on plant growth and development: Absolute versus relative amounts of blue light. HortScience 48:504-509.

Craig, D.S. and E.S. Runkle. 2012. Using LEDs to quantify the effect of the red to far-red ratio of night-interruption lighting on flowering of photoperiodic crops. Acta Hort. 956:179-185.

de Mendiburu, F. 2016. Agricolae: Statistical procedures for agricultural research. $\mathrm{R}$ package version 1.2-4

Demotes-Mainard, S., T. Péron, A. Corot, J. Bertheloot, J. Le Gourrierec, S. Pelleschi-Travier, L. Crespel, P. Morel, L. Huché-Thélier, R. Boumaza, A. Vian, V. Guérin, N. Leduc, and S. Sakr. 2016. Plant responses to red and far-red lights, applications in horticulture. Environ. Expt. Bot. 121:4-21.

Faust, J.E. 2003. Light. In: D. Hamrick (ed.). Ball RedBook, Vol. 2: Crop production. 17th ed. Ball Publishing, Batavia, IL.

Faust, J.E., P.C. Korczynski, and U.C. Samarakoon. 2014. Quantifying the effects of hanging baskets on the greenhouse light environment. HortTechnology 24:369-373.

Fletcher, J.M., A. Tatsiopoulou, M. Mpezamihigo, J.G. Carew, R.G.C. Henbest, and P. Hadley. 2005. Far-red light filtering by plastic film, greenhouse-cladding materials: Effects on growth and flowering in Petunia and Impatiens. J. Hort. Sci. Biotechnol. 80:303-306.

Folta, K.M. and K.S. Childers. 2008. Light as a growth regulator: Controlling plant biology 
with narrow-bandwidth solid-state lighting systems. HortScience 43:1957-1964.

Gates, D.M., H.J. Keegan, J.C. Schleter, and V.R. Weidner. 1965. Spectral properties of plants. Appl. Opt. 4:11-20.

Goldberg, B. and W.H. Klein. 1977. Variations in the spectral distribution of daylight at various geographical locations on the Earth's surface. Sol. Energy 19:3-13.

Hamrick, D. 2003. Growth regulators. In: Ball RedBook, Vol. 2: Crop production. 17th ed. Ball Publishing, Batavia, IL.

Heraut-Bron, V., C. Robin, C. Varlet-Grancher, D. Afif, and A. Guckert. 1999. Light quality (red: far-red ratio): Does it affect photosynthetic activity, net $\mathrm{CO}_{2}$ assimilation, and morphology of young white clover leaves? Can. J. Bot. 77:1425-1431.

Hernández, R. and C. Kubota. 2016. Physiological responses of cucumber seedlings under different blue and red photon flux ratios using LEDs. Environ. Expt. Bot. 121:66-74.

Holmes, M.G. and H. Smith. 1975. The function of phytochrome in plants growing in the natural environment. Nature 254:512-514.

Holmes, M.G. and H. Smith. 1977a. The function of phytochrome in the natural environmentII. The influence of vegetation canopies on the spectral energy distribution of natural daylight. Photochem. Photobiol. 25:539-545.

Holmes, M.G. and H. Smith. 1977b. The function of phytochrome in the natural environment- $\mathrm{I}$. Characterization of daylight for studies in photomorphogenesis and photoperiodism. Photochem. Photobiol. 25:533-538.

Holmes, M.G. and H. Smith. 1977c. The function of phytochrome in the natural environmentIV. Light quality and plant development. Photochem. Photobiol. 25:551-557.

Ilias, I.F. and N. Rajapakse. 2005. The effects of end-of-the-day red and far-red light on growth and flowering of Petunia $\times$ hybrida "Countdown Burgundy" grown under photoselective films. HortScience 40:131-133.

Johkan, M., K. Shoji, F. Goto, S. Hashida, and T. Yoshihara. 2010. Blue light-emitting diode light irradiation of seedlings improves seedling quality and growth after transplanting in red leaf lettuce. HortScience 45:1809-1814.

Kasperbauer, M.J. 1987. Far-red light reflection from green leaves and effects on phytochromemediated assimilate partitioning under field conditions. Plant Physiol. 85:350-354.

Kasperbauer, M.J. and D.E. Peaslee. 1973. Morphology and photosynthetic efficiency of tobacco leaves that received end-of-day red or far red light during development. Plant Physiol. $52: 440-442$.

Kessler, J.R., Jr. 2004. Growing and marketing bedding plants. ANR-559. Alabama Coop. Ext. System. Alabama A\&M Univ., Huntsville, AL.
Kim, H., G.D. Goins, R.M. Wheeler, and J.C. Sager. 2004. Green-light supplementation for enhanced lettuce growth under red- and bluelight-emitting diodes. HortScience 39:16171622.

Kittas, C., A. Baille, and P. Giaglaras. 1999. Influence of covering material and shading on the spectral distribution of light in greenhouses. J. Agr. Eng. Res. 73:341-351.

Kubota, S., T. Yamato, T. Hisamatsu, E. Sadayuki, R. Oi, M.S. Roh, and M. Koshioka. 2000. Effects of red- and far-red- rich spectral treatments and diurnal temperature alternation on the growth and development of Petunia. J. Jpn. Soc. Hort. Sci. 69:403-409.

Li, Q. and C. Kubota. 2009. Effects of supplemental light quality on growth and phytochemicals of baby leaf lettuce. Environ. Expt. Bot. 67:59 64.

Liakopoulos, G. and I. Spanorigas. 2012. Foliar anthocyanins in Pelargonium $\times$ hortorum are unable to alleviate light stress under photoinhibitory conditions. Photosynthetica 50:254 262.

Llewellyn, D., Y. Zheng, and M. Dixon. 2013. Survey of how hanging baskets influence the light environment at lower crop level in ornamental greenhouses in Ontario, Canada. HortTechnology 23:823-829.

Lund, J.B., T.J. Blom, and J.M. Aaslyng. 2007. End-of-day lighting with different red/far-red ratios using light-emitting diodes affects plant growth of Chrysanthemum $\times$ morifolium Ramat. "Coral Charm.". HortScience 42:1609-1611.

Meng, Q. and E.S. Runkle. 2014. Controlling flowering of photoperiodic ornamental crops with light-emitting diode lamps: A coordinated grower trial. HortTechnology 1:702-711.

Moe, R., R.D. Heins, and J. Erwin. 1991. Stem elongation and flowering of the long-day plant Campanula isophylla Moretti in response to day and night temperature alternations and light quality. Scientia Hort. 48:141-151.

Qaderi, M.M., V.J. Godin, and D.M. Reid. 2015. Single and combined effects of temperature and red:far-red light ratio on evening primrose (Oenothera biennis). Botany 93:475-483.

R Core Team. 2016. R: A language and environment for statistical computing. R Foundation for Statistical Computing, Vienna, Austria.

RStudio Team. 2016. RStudio: Integrated development environment for R. RStudio, Inc., Boston, MA.

Runkle, E.S. and R.D. Heins. 2001. Specific functions of red, far red, and blue light in flowering and stem extension of long-day plants. J. Amer. Soc. Hort. Sci. 126:275-282.

Sager, J.C. and J.C. McFarlane. 1997. Radiation. In: R.W. Langhans and T.W. Tibbitts (eds.). Plant growth chamber handbook. North Central Regional Res. Publ. No. 340. Iowa Agr. Home
Economics Expt. Sta. Spec. Rpt. No. 99. Iowa State Univ. Press, Ames, IA.

Sager, J.C., W.O. Smith, J.L. Edwards, and K.L. Cyr. 1988. Photosynthetic efficiency and phytochrome photoequilibria determination using spectral data. Trans. ASAE 31:18821889.

Smith, H. and M.G. Holmes. 1977. The function of phytochrome in the natural environment-III. Measurement and calculation of phytochrome photoequilibria. Photochem. Photobiol. 25:547550 .

Smith, H. and G.C. Whitelam. 1997. The shade avoidance syndrome: Multiple responses mediated by multiple phytochromes. Plant Cell Environ. 20:840-844.

Son, K.H. and M.M. Oh. 2013. Leaf shape, growth, and antioxidant phenolic compounds of two lettuce cultivars grown under various combinations of blue and red light-emitting diodes. HortScience 48:988-995.

Trupkin, S.A., M. Legris, A.S. Buchovsky, M.B. Rivero, and J.J. Casal. 2014. Phytochrome B nuclear bodies respond to the low red to far-red ratio and to the reduced irradiance of canopy shade in Arabidopsis. Plant Physiol. 165:16981708.

Tsormpatsidis, E., R.G.C. Henbest, F.J. Davis, N.H. Battey, P. Hadley, and A. Wagstaffe. 2008. UV irradiance as a major influence on growth, development and secondary products of commercial importance in Lollo Rosso lettuce "Revolution" grown under polyethylene films. Environ. Expt. Bot. 63:232-239.

Tucker, D.J. 1981. Phytochrome regulation of leaf senescence in cucumber and tomato. Plant Sci. Lett. 23:103-108.

Wargent, J.J. 2016. UV LEDs in horticulture: From biology to application. Acta Hort. 1134:25-32.

Wickham, H. and R. Francois. 2016. Dplyr: A grammar of data manipulation. $\mathrm{R}$ package version 0.5.0.

Xiong, J., G.G. Patil, and R. Moe. 2002. Effect of DIF and end-of-day light quality on stem elongation in Cucumis sativus. Scientia Hort. 94:219-229.

Xiong, J., G.G. Patil, R. Moe, and S. Torre. 2011. Effects of diurnal temperature alternations and light quality on growth, morphogenesis and carbohydrate content of Cucumis sativus L. Scientia Hort. 128:54-60.

Yang, Z.C., C. Kubota, P.L. Chia, and M. Kacira. 2012. Effect of end-of-day far-red light from a movable LED fixture on squash rootstock hypocotyl elongation. Scientia Hort. 136:8186.

Zhou, B., Y. Li, Z. Xu, H. Yan, S. Homma, and S. Kawabata. 2007. Ultraviolet A-specific induction of anthocyanin biosynthesis in the swollen hypocotyls of turnip (Brassica rapa). J. Expt. Bot. 58:1771-1781. 